The Journal of Animal \& Plant Sciences, 30(5): 2020, Page: 1215-1223

ISSN (print): 1018-7081; ISSN (online): 2309-8694

\title{
COMPARATIVE INVESTIGATION OF PALYNOLOGICAL CHARACTERS OF CUSCUTA REFLEXA AND FEW MEMEBERS OF CONVOLVULACEAE
}

\author{
Q. Noshad ${ }^{* 1}$, M. Ajaib ${ }^{* 1}$ and A. Kiran ${ }^{2}$ \\ ${ }^{1}$ Department of Botany Mirpur University of Science and Technology (MUST), Mirpur-10250(AJK), Pakistan \\ ${ }^{2}$ Department of Botany, University of Agriculture Faisalabad \\ *Corresponding author’s email: majaibchaudhry@yahoo.com, qumqum_noshad@yahoo.com
}

\begin{abstract}
Cuscuta reflexa Roxb. belonging to family Cuscutaceae was explored for its pollen morphology and its pollen characters examined with light and scanning electron microscope were compared with six species belonging to family Convolvulaceae. Pollen samples were collected from Districts; Kotli, Bhimber and Mirpur, Azad Jammu \& Kashmir, Pakistan. Flowers of Cuscuta reflexa Roxb., five species of Ipomoea including Ipomoea carnea Jacq., Ipomoea cairica (L.) Sweet , Ipomoea hederacia Jacq., Ipomoea pes-tigridi sL., Ipomoea eriocarpa R.Br., Ipomoea arachnosperma Welw. and Convolvulus arvensis L. were collected. Pollen shape of these selected species are generally prolate, subprolate, prolate-spheroidal, oblate spheroidal and perpolate. The apertures of the pollens of these taxa were found scabrate, scabrate-perforate, reticulate and echinate-reticulate. Among the examined taxa, $C$. reflexa Roxb. has smallest size of pollen $(2-5 \times 2.5-5 \mathrm{pm})$ while the largest pollen $(28.5-37.6 \times 24.7-28.9 \mathrm{pm})$ belongs to the Ipomoe acarnea. It has been founded that pollen of Cuscuta reflexa Roxb. is prolate in shape and was similar to I. carnea Jacq, I. pes-tigridis $\mathrm{L}$, I. eriocarpa $\mathrm{R} . \mathrm{Br}$ pollens. Hierarchical cluster analysis based on pollens observations grouped I. arachnosperma and Cuscuta refelexa together at maximum similarity 99.86 at a distance level of 0.003 . It has been concluded from this study that Cuscuta refelexa pollen are exactly similar to Ipomea arachnosperma on the bases of pollen morphology and exine appearance.
\end{abstract}

Keywords: Ipomea, Pollen, SEM, Cuscuta.

https://doi.org/10.36899/JAPS.2020.5.0139

Published online June 25, 2020

\section{INTRODUCTION}

The significance of pollen morphology in the taxonomy of Convolvulaceae has been investigated by many workers (Rajurkar et al.,2011). The morning glory family (Convolvulaceae) is a stunning family which is broadly cultivated for its ornamental values. In tropical and temperate regions almost 55 genera and 1930 species of the Convolvulaceae are extensively dispersed all through and abundant in tropical America and tropical Asia (Sunar et al.,2012). Ipomoea is the key genus represented by 600 species (Judd et al., 2002). In temperate region the family is, represented by the bestknown weedy representatives, i.e. Convolvulus and Calystegia. A customary position of the family Convolvulaceae is in the order Solanales (Thorne, 1992). On the basis of molecular phylogenetic studies, it was suggested that family Convolvulaceae is closely related to the Montiniaceae and Solanaceae (Olmstead and Palmer 1992; Olmstead ,2004; Soltis et al.,2000; Stefanovic et al., 2003).

Palynology is the study of pollen and spores. The word palynology was first proposed by Hyde and William (1945). Today, little is known about the pollen morphology of Cuscuta species. Species diversity was evaluated by studying the importance of pollen properties, palynological features such as spine strength spine length and aperture type in the discrimination of taxa. Shape of pollen ranges from spheroidal to prolates pheroidal (Reshmi and Rajalakshmi 2019). The palynological morphological characters are taxonomically important in identification and demarcation of species (Ullah et al.,2018).

According to Welsh et al (2010), pollen morphology is used to find out the relationships of members of the Convolvulaceae family. Sudhama et al., (2019) compared eight species of Ipomea on the bases of pollen morphology and described oblate spheroidal pollen shape spinose exine with pentaporate apperture. Parveen and Qaiser (2004) investigated eleven species of Cuscutaceae from Pakistan by the use of light and scanning electron microscope and founded three types of pollen shapes.

Convolvulaceae and Cuscutaceae families have characters that are common in genus Ipomoae and Merremia. This study was carried out to study the variation of selected genera from both families to indicate that whether these two families are homogeneous or heterogenous on the bases of pollen characters. 


\section{MATERIALS AND METHODS}

Field Surveys and Collecting the Samples: This study was carried out during 2017-2018. Samples of flowers for the study of pollen morphology was collected during September and November when pollens were fully mature belonging to the genus Cuscuta reflexa Roxb., genus Ipomoea including I. carnea Jacq., Ipomoea cairica (L.) Sweet, I. hederacia Jacq., I.pes-tigridis L., I . eriocarpa R.Br., I. arachnosperma Welw. and one species of the genus Convolvulus i.e. Convolvulus arvensis L., from different geographical regions in district Kotli, District Bhimber and District Mirpur as indicated in the Flora of Pakistan (Davis, 1978) (Table1).

Table1. Geographic distribution of 7 taxa and their flowering period.

\begin{tabular}{lll}
\hline Taxon & Collection Site & Flowering period \\
\hline Ipomoea cairica $(\mathrm{L})$. & District Bhimber & June-December \\
I. carnea Jacq. & District Kotli & July-November \\
I. hederacia Jacq. & District Bhimber & September-October \\
I.pes-tigridis L & District Bhimber & September-October \\
I. eriocarpa R.Br., & District Bhimber & August-October \\
Convolvulus arvensis & District Kotli & All the year \\
Cascuta reflexa Roxb & District Mirpur & November-Feburary \\
I. arachnosperma Welw & District Bhimber & August-November \\
\hline
\end{tabular}

Light microscopic (LM) and Scanning Electron Microscopic (SEM) characters: LM observations were made on fully mature pollens that were fixed on slide from an anther at anthesis stage, to mount pollen grains glycerine jelly was used and for staining purpose safranine was used. A drop of alcohol was added to remove the oily and resinous substances and then examined using oil emersion. The photograph was taken with Stereo zoom microscope IM-SC-500. Pollen were measured on the bases of equatorial diameter (E) Polar diameter $(\mathrm{P})$ and sphericity $(\mathrm{P} / \mathrm{E}$ ratio). Twenty pollen grains were considered for each measurement and the arithmetic mean was calculated for every diameter (Erdtman, 1952) . Pollen size, was measured according to Walker \& Doyle (1975) standards: minute grain $<10 \mu \mathrm{m}$; small grain $10-24 \mu \mathrm{m}$; medium grain $25-49 \mu \mathrm{m}$; large grain $50-99 \mu \mathrm{m}$; very large grain $100-199 \mu \mathrm{m}$ and gigantic grain $<$ or $=>200 \mu \mathrm{m}$.

For scanning electron microscopy (SEM) pollen slides were prepared by using the technique of Jones \& Pucci (2012). Pollen grains were suspended in a drop of $40 \%$ acetic acid and then transferred to clear metallic stub. Stubs were covered with double-stick tape and pollen grain were placed on to the stubs and samples were stored for 24 hours at $28-30^{\circ} \mathrm{C}$. After all the samples were prepared, the stubs were coated with a thin layer of gold by a Polar on SC502 sputter coater. They were examined under the scanning electron microscope (Jeol JSM-840-A, Japan). To measure the size of the pollens equatorial axis and polar axis were considered by the measurement of 30 pollen grains per sample. Pollens were characterized in size as small $(10-25 \mathrm{pm})$ or medium (25-50 pm) according to Erdtman (1952). The terminology used is mainly from Punt et al. (2007). Shape classification follows Erdtman (1969), based on
$\mathrm{P} / \mathrm{E}$ ratios in the Table. The minimum and maximum range values and standard deviations (STD) of the measured grains were also determined.

Hierarchical cluster analysis of variables: Hierarchical cluster analysis of variables was performed on the basis of six observed variables (Polar length $(\mu \mathrm{m} \pm$ STD Equatorial length $(\mu \mathrm{m} \pm \mathrm{STD}) \mathrm{P} / \mathrm{E}$ ratio Exine thickness $\mathrm{pm} \pm$ STD Spine Width (pm) Spine length $(\mathrm{pm})$ with the help of MINITAB Software and maximum similarity level is shown on $\mathrm{X}$-axis and species on $\mathrm{Y}$ axis (Abdel Khalik, 2008).

\section{RESULTS}

General Morphology of the Flower of the Convolvulaceae: Flower in terminal or axillary simple or compound cymose inflorescence, bisexual mostly actinomorphic. Sepals 5, free corolla of 5 sympetalous stamens 5 epipetalous free anther 2 locular, carpel 2 rarely 3 , ovary superior ovule 2 , styles 2 ; stigma capitate or linear.

General Morphology of the Flower of the Cuscutacea: Flower are arranged in paniculate cyme white, pedicellate 5.5 to $7.5 \mathrm{~mm}$ long, bract leaf like calyx lobes 5,fleshy margin, corrolla lobes 5 , ivory white $1-1.5 \mathrm{~mm}$, corolla tube 2-3 $\mathrm{mm}$ long; scales $1 \mathrm{~mm}$ long stamens five filamentous linear 2-3 mm long, anther oblong basifixed 1-1.5 mm long ovary conical fleshy, ovule 4, capsule1$3 \mathrm{~mm}$ globose style and stigma at the top.

Selected species of Convolvulaceae and Cuscutaceae were collected from District Kotli, Bhimber and Mirpur. Among the examined taxa, C. reflexa Roxb. has smallest size of pollen $(2-5 \times 2.5-5 \mathrm{pm})$ while the largest pollen $(28.5-37.6 \times 24.7-28.9 \mathrm{pm})$ belongs to the Ipomoea carnea (Fig.1). Pollen shape of these selected 
species are generally prolate, subprolate, prolatespheroidal, oblate spheroidal and perpolate.

Observations: Characteristics of pollens of selected species as observed under SEM and LM are summarized here;

Cuscuta reflexa Roxb: Pollen shape of this species is prolate, $(\mathrm{P} / \mathrm{E} 1.7)$, size; $(2-5 \times 2.5-5 \mathrm{pm})$ categorized as small. Exine thickness is $0.53 \mathrm{pm}$, spine length $5 \mathrm{pm}$ spine 2.5 pm. Exine are scabrate perforate (Table 2; Fig.1).

Ipomoea cairica (L.) sweet: Pollen shape was oblatespheroidal, (P/E 0.96), size; (27.6-29.4×17.2-20.4 pm) categorized as medium. Exine thickness was $1.04 \mathrm{pm}$, exine spine width $2.5 \mathrm{pm}$, spine length $5 \mathrm{pm}$. Exine are scabrate (Table2; Fig.1).

I. carnea Jacq: Pollen form of this taxon is prolate, (P/E.1.58), size; (28.5-37.6 x2 4.7-28.9pm) categorized as medium. Exine thickness $1.25 \mathrm{pm}$, spine width 3.75 $\mathrm{pm}$, spine length $8.75 \mathrm{pm}$. Exine were reticulate (Table 2; Fig.1).

I. hederacia Jacq : Pollen shape of this taxon was prolate- spheroidal, $(\mathrm{P} / \mathrm{E} 1.02)$, size; $(22.8 \times 22.7 \mathrm{pm})$ categorized as medium. Spine width $2.5 \mathrm{pm}$, spine length $5 \mathrm{pm}$. Exine are echinate reticulate (Table 2; Fig.1).

I. pes-tigridis L.: Pollen shape of this taxon is prolate $(\mathrm{P} / \mathrm{E} 1.82)$, size; $(24.3-22.6 \times 22.8-20.7 \mathrm{pm})$ categorized as medium. Exine thickness $0.51 \mathrm{pm}$, spine width 1.25 $\mathrm{pm}$, spine length $5 \mathrm{pm}$. Exine are echinate-reticulate (Table 2; Fig.1).

I. eriocarpa R.Br.: Pollen shape of this taxon is prolate, $(\mathrm{P} / \mathrm{E}$ 1.98), size: $(24.8-30.3 \times 17.1-18.4 \mathrm{pm})$. Exine thickness $0.85 \mathrm{pm}$, spine width $2.5 \mathrm{pm}$, spine length 3.75 . Exine are markedly scabrate(Table2;Fig.1).

Convolvulu sarvensis L.: Pollen shape is oblate spheroidal (P/E 0.94), size: (19.1-26.2×12.8-16.6 pm) categorized as small. Exine thickness $0.37 \mathrm{pm}$, spine width $2.5 \mathrm{pm}$, spine length $5 \mathrm{pm}$, Exine are very distinctly scabrate (Table 2; Fig.1).

I. arachnosperma Welw: Pollen shape of this taxon is oblate spheroidal (P/E 1.98), size; $(24.8-30.3 \times 17.1$ $18.4 \mathrm{pm}$ ) catagorized as medium. Exine thickness $0.37 \mathrm{pm}$, spine length $2.5 \mathrm{pm}$, width $1.5 \mathrm{pm}$, spine length $2.5 \mathrm{pm}$. Exine are scabrate (Table 2; Fig.1)

Hierarchical cluster analysis of variables: Hierarchical cluster analysis of variables was done on the basis of six observed variables (Polar length $(\mu \mathrm{m} \pm \mathrm{STD}) \quad$ Equatorial length $(\mu \mathrm{m} \pm \mathrm{STD}) \mathrm{P} / \mathrm{E}$ ratio Exine thickness $\mathrm{pm} \pm \mathrm{STD}$ Spine Width $(\mathrm{pm})$ Spine length(pm) with the help of MINITAB Softaware maximum similarity observed was 99.86 at a distance level of 0.003 that is between $I$. arachnosperma and Cuscuta refelexa (Table3;Fig.2). 


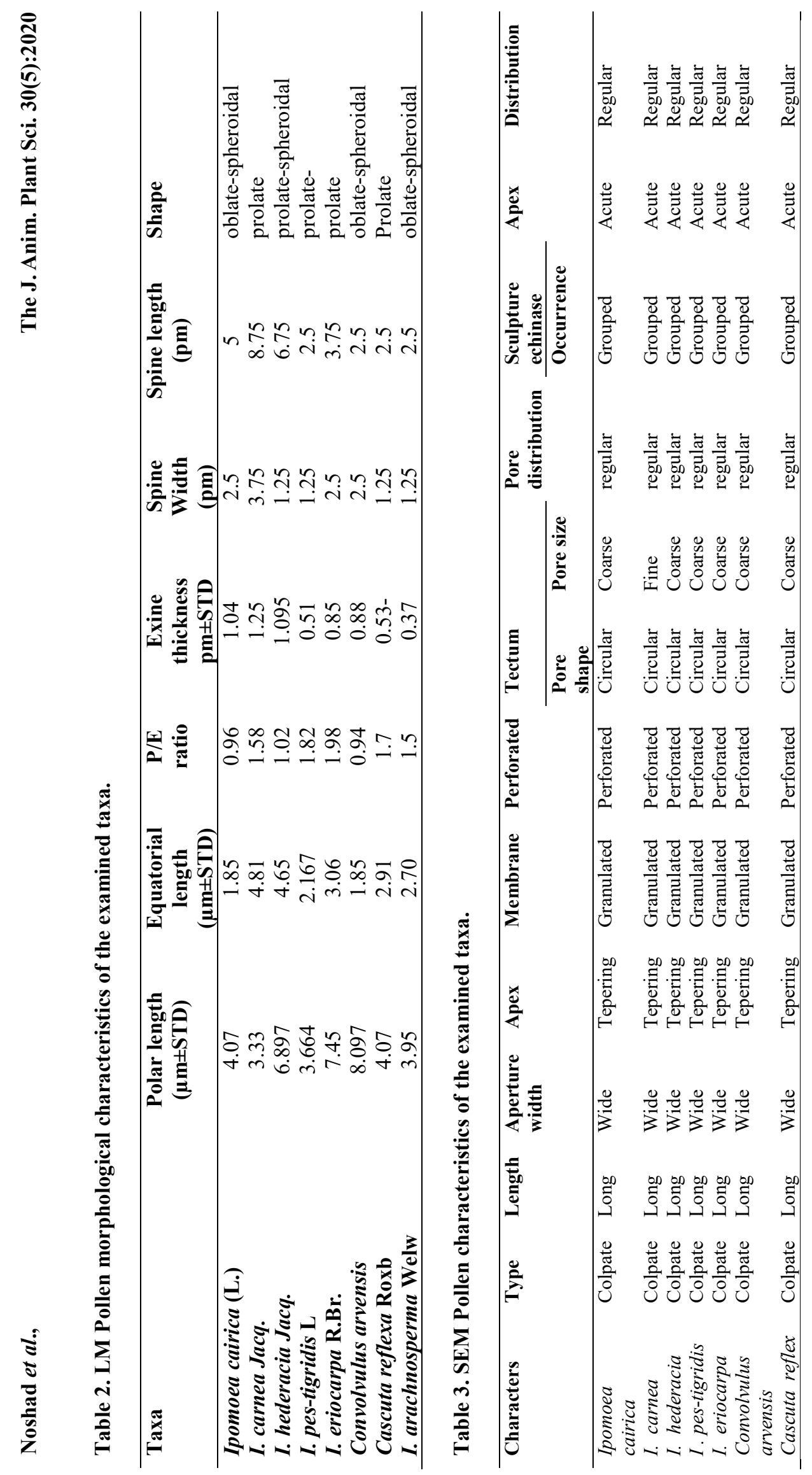



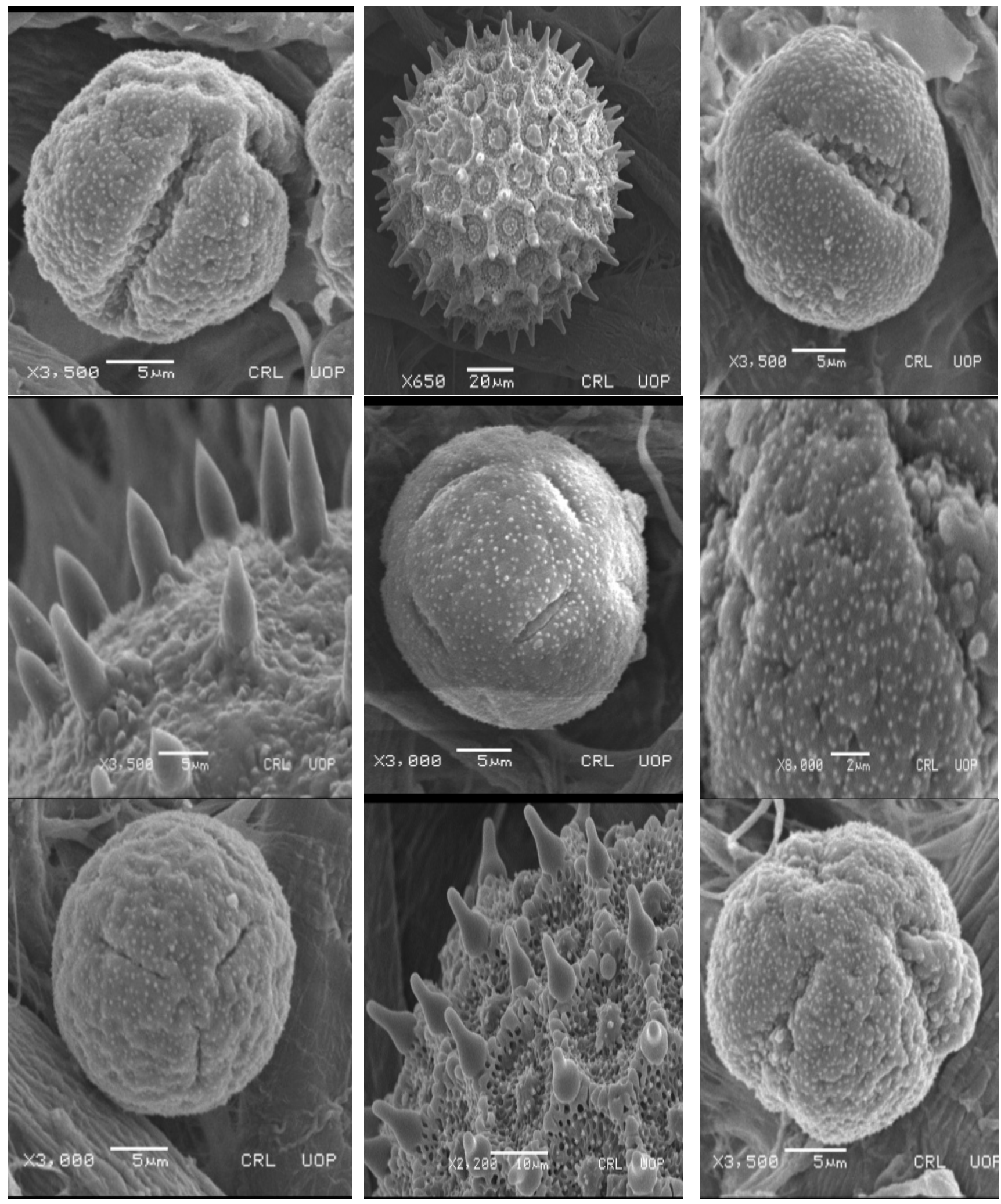

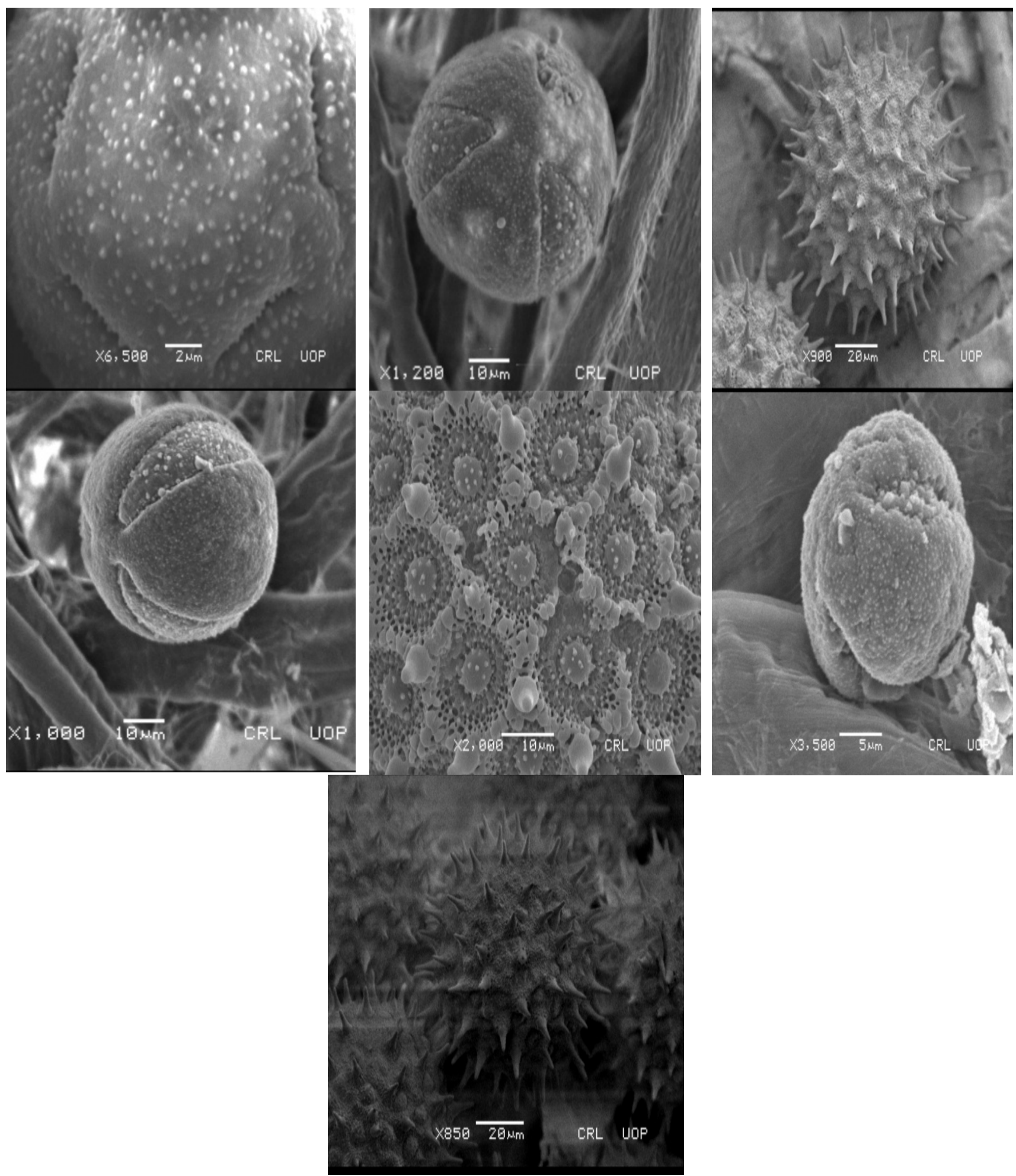

Figure 1. SEM pollen images of : A. Cuscuta refelexa a: equatorial view of pollens, B detail of exine showing the perforate, scabrate ornamentation; Convolvulus arvensis C: Equatorial view, D detail of exine showing the distinctly scarbrate Ipomoea carnea $\mathbf{E}$ colpus, D: Exine reticulate Ipomoea cairica (L.) Sweet G equatorial view Exine scarbrate; I. hederacia Jacq. I. equatorial view J detail of exine echinate reticulate; I.eriocarpa R.Br., K Equatorial view L detail of exine showing the perforate; I. pes-tigridis $\mathrm{M}$ equatorial view $\mathrm{N}$ exine echinate reticulate; I. arachnosperma Welw equatorial view P. Exine; markedly scarbate 
Table4.Hierarchical cluster analysis of variables.

\begin{tabular}{lccccccc}
\hline Steps & $\begin{array}{c}\text { No of } \\
\text { Clusters }\end{array}$ & $\begin{array}{c}\text { Similarity } \\
\text { level }\end{array}$ & $\begin{array}{c}\text { Distance } \\
\text { level }\end{array}$ & $\begin{array}{c}\text { Cluster } \\
\text { joined }\end{array}$ & $\begin{array}{c}\text { New } \\
\text { cluster }\end{array}$ & $\begin{array}{c}\text { No of observation in new } \\
\text { cluster }\end{array}$ \\
\hline 1 & 7 & 99.86 & 0.003 & 7 & 8 & 7 & 2 \\
2 & 6 & 98.90 & 0.022 & 4 & 7 & 4 & 3 \\
3 & 5 & 98.11 & 0.038 & 5 & 6 & 5 & 2 \\
4 & 4 & 97.01 & 0.060 & 4 & 5 & 4 & 5 \\
5 & 3 & 94.17 & 0.117 & 3 & 4 & 3 & 6 \\
6 & 2 & 92.96 & 0.147 & 1 & 3 & 1 & 7 \\
7 & 1 & 90.22 & 0.196 & 1 & 2 & 1 & 8 \\
\hline
\end{tabular}

\section{Similarity}

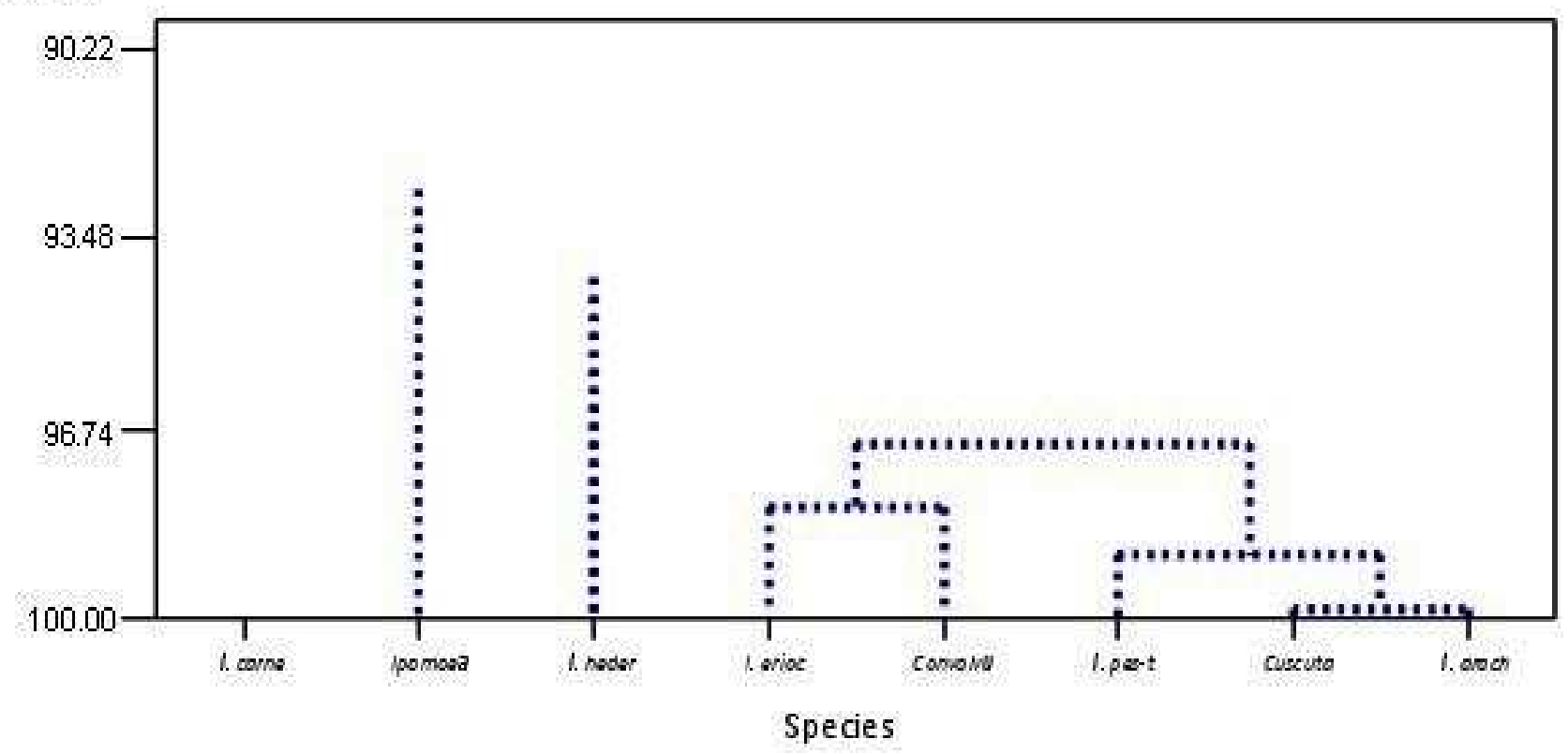

Figure 2. Hierarchical cluster analysis of variables was done on the basis of six observed variables (Polar length $(\mu \mathrm{m} \pm \mathrm{STD})$ Equatorial length $(\mu \mathrm{m} \pm \mathrm{STD}) \mathrm{P} / \mathbf{E}$ ratio Exine thickness $\mathbf{p m} \pm \mathrm{STD}$ Spine Width (pm) Spine length (pm) similarity level is shown on $\mathrm{X}$-axis and species on $\mathrm{Y}$ axis. Cluster 1 represents Ipomoea carnea, cluster 2 Ipomoea cairica (L.) Sweet cluster 3, I.hederacia Jacq. and Cuscuta refelexa, Convolvulus arvensis, I.pes-tigridis, I. arachnosperma are in cluster 4.

\section{DISCUSSION}

Palynological identification has its worth since long as found in literature for the multiple applications and uses of pollens by American botanist Wodehouse in1935 (Wodehouse, 1935). Moreover, Swedish botanist Erdtman developed method of acetolysis for detailed study of pollen morphology and emphasized on their role for the taxonomic classification of taxa (Erdtman,1952). Pollens are proved important for their use to recognize the vegetal organism which produce them.

This study was also planned to compare the palynological characters of species Cuscuta reflexa Roxb with selected species of Convolvulaceae. The pollen morphology of Convolvulaceae is known to be a highly diverse and has a taxanomoic importance (Telleria and Daners, 2003).

The present study noted echinate and pantoporate characters in two Ipomoea species i.e in $I$. hederacia and Ipomea pestigridis, these finding are exactly similar to that of Erdtman (1971) and Rao and Lee (1970) observations. In five species i.e Ipomea cairica, Ipomea carnea, I. arachnosperma Convolvulus arvensis exine are scabrate perforate ornamentaion this was in accordance with the studies of Sudhama et al (2019). In Convolvulus arvensis pollen shape is oblate spheroidal this was in accordance with work of TeKin and YilMaz (2016).

The smallest pollen grains are those of Cuscuta reflexa Roxb. size; $(2-5 \times 2.5-5 \mathrm{pm})$ categorized as small and largest pollen (28.5-37.6 x 24.7-28.9 pm) belongs to 
the Ipomoea carnea. Pollen size of other taxa ranged between (19.1-26.2×12.8-16.6pm)-(27.6-29.4×17.2$20.4 \mathrm{pm}$ ). Shape of pollen grains prolate-spheroidal, spheroidal, oblate-spheroidal, sub oblate to subprolate. Similar observations are reported by some other studies that pollen shapes of Cuscuta species are oblate, suboblate, subprolate, spheroidal, oblate-spheroidal, and prolate spheroidal (Lia et al., 2000); Perveen and Qaiser, 2004; Welsh et al.,2010).

Pollen observed in this study were colpate with colpi apertures. All the species distinguished on the basis of granulated pore membrane, exine structure and nature of pore. On the bases of pore, exine of I. eriocarpa R.Br., was perforated, the grains are perforate and pores are irregular in shape while in I. hederacia Jacq echinate reticulate. Based on Hierarchical cluster analysis of species maximum similarity was observed between $I$. arachnosperma and Cuscuta reflexa which was also reported by Abdel Khalik (2008).

Conclusion: On the basis of pollen morphology it has been founded that Cuscuta has close resemblence with Ipomea species. The pollens of these taxa are generally identified as oblate spheriodal prolate, subprolate, prolate spheroidal and perpolate. On the basis of our study it is concluded that genus Cuscuta placed in Convolvulacea due to most of similarities with other genera because prolate in shape and was similar to I. carnea Jacq, I.pestigridis L, I. eriocarpa R.Br pollens as found by Sengupta (1972).

\section{REFERENCES}

Abdel Khalik, K. A. (2008) Phenetic study of Convolvulaceae from Egypt based on analysis of morphological characters. Fl. Medit. 18:65-87.

Davis, P. H., (1978). Flora of Turkey and the East Aegean Islands, 6. Edinburgh Univ. Press. Edinburgh, UK.

Erdtman, G. (1952). Pollen Morphology and Plant Taxonomy-Angiosperms: An Introduction to Palynology, 1:539.

Erdtman, G. (1969) Handbook of Palynology, An introduction to the study of pollen grains and Spores.-Copenhagen.

Erdtman, G. (1971). Pollen Morphology and Plant Taxonomy. Hafner Pub. Co., NewYork

Hyde,H.A. and D.W. Williams, (1945) Rightword, Pollen Analysis Circular 8:6

Jones,G.D. and T.M. Pucci (2012). Pollen analysis of Agathirsiawasps. Grana,51:305-317

Judd,S.W., S.C. Campbell, A. E. Kellogg, F.P. Stevens, and J.M. Donoghue, (2002) Plant Systematics: A Phylogenetic Approach. 2nd ed. Massachusettes, USA: Sinauer Associates, Inc.
Liao, G.I.,M.Y Chen, and C.S. Kuoh, (2000). Cuscuta L. (Convolvulaceae) in Taiwan. Taiwania, 45: 226234

Olmstead R. G. (2004). Testing the phylogenetic position of a parasitic plant (Cuscuta, Convolvulaceae, Asteridae): Bayesian inference and the parametric bootstrap on data drawn from three genomes.Syst. Biol. 53(3): 384-399

Olmstead, R. G. \& J. D. Palmer (1992). A chloroplast DNA phylogeny of the Solanaceae: sub familial relationships and characters evolution.-Ann. Missouri Bot. Gard.79: 346-360.

Perveen, A. and M. Qaiser (2004). Pollen Flora of Pakistan. XII. Convolvulaceae. Bang 1. J. Bot., 27:109-1189

Punt, W., P. P. Hoen, S. Blackmore and A. L.Thomas (2007). Glossary of pollen and spore terminology. Rev. Paleobot. Palynol.,143:1-81

Reshmi, G.R. and R. Rajalakshmi (2019). Systematic Significance of Pollen Morphology of the Genus Acmella Rich. (Heliantheae: Asteraceae). Iranian J. of Sci ., and Technol. 43:1469-1478.

Rajurkar A. V., J. A Tidke and G.V. Patil, (2011) Res in Pla Biol., 1(5): 41-47.

Rao. A.N. and Y. K. Lee, (1970) Studies on Singapore pollen. Pacisci 24: 255-268.

Sengupta, S. (1972) On the pollen morphology of Convolvulaceae with special reference to taxonomy. - Rev. Palaeobot. Palynol. 13: 157212.

Stefanovic, S, D .F., Austin, R. G. Olmstead, (2003). Classification of Convolvulaceae: A phylogenetic Approach.-Syst. Bot. 28 (4): 791-806.

Sunar, S., N. Yildirim, O. Aksakal, G. Agar (2012). Determination of the toxic effects of Convolvulus arvensis extracts on corn (Zea mays L.) seeds. Department of Biology, Ataturk University, Erzurum, Turkey

Soltis, D. E., P.S. Soltis, N.M. Chase, M.E. Mort, M.E., Al-Bach, D.C., Zanis, M., Savolainen, V., Hahn, W.H., Hoot, S.B., Fay, M.F., Axtell , M., Swensen, L.M Prince, W.J. Kress, K.C. Nixon, and J.S. Farris (2000). Angiosperm phylogeny inferred from 18SrDNA, rbcL, and at $\mathrm{pB}$ sequences.-Bot. J. Linn. Soc.133:381-461.

Sudhama, V. N and S. Kumar, (2019) Studies on pollen morphology of selected species of Convolvulacea in Chikkamagaluru Taluk of Karnataka-State India. JSRR 8 (2): 48-54

Tekin, M. and G. Yilmaz, (2016) Palynological Studies of the Genus Convolvulus L. (Convolvulaceae) from Turkey. Botanical Sci.,94(3):543-549

Telleria, M.C. and G. Daners (2003) Pollen types in Southern new world Convolvulaceae and their taxonomic significance. Plant Syst. Evol. 243:99118 
Thorne, R. F. (1992). An updated phylogenetic classification of flowering plants. Aliso: A J. Systematic and Evolutionary Botany 13 (2):365389

Ullah, F., M. Zafar, M. Ahmad, S. Dilbar, S.N. Shah, A. Sohail, W. Zaman, M. Iqbal, S. Bahadur and A. Tariq (2018). Pollen morphology of subfamily Caryophylloideae (Caryophyllaceae) and its taxonomic significance. Micro. Res. and Technol. 81(7): 704-715.
Walker, J. W. and J.A. Doyle, (1975). The bases of angiosperm phylogeny: palynology. Ann. Missouri Bot. Gard., 62: 664-723.

Welsh, M., S. Stefanovic and M. Costea, (2010). Pollen evolution and its taxonomic significance in Cuscuta (dodders, Convolvulaceae). Plant. Syst. Evol, 285:83-101.

Wodehouse, R.P., (1935). Pollen Grains, Their Structure, Identifications and Significance in Science and Medicine. p. 574. Mc. Graw-Hill Book Co., New York and London. 